\title{
EMPLOYEES' GOAL ORIENTATIONS, THE QUALITY OF LEADER-MEMBER EXCHANGE, AND THE OUTCOMES OF JOB PERFORMANCE AND JOB SATISFACTION
}

\author{
ONNE JANSSEN \\ NICO W. VAN YPEREN \\ University of Groningen
}

\begin{abstract}
As hypothesized, data from 170 employees of a Dutch firm showed that the quality of leader-member exchange mediated positive relationships between a mastery orientation and leader-rated in-role job performance, leader-rated innovative job performance, and job satisfaction. In contrast, a performance orientation was negatively related or unrelated to those outcomes. These findings suggest that employees with stronger mastery orientations are more effective on the job because they tend to establish higher-quality exchanges with their supervisors.
\end{abstract}

Important and recurring questions in organizational science are why employees perform well in their jobs and why they are satisfied with their jobs. Achievement goal theory and research suggest that employees' job performance and job satisfaction depend on their goal orientations (e.g., Farr, Hofmann, \& Ringenbach, 1993; Phillips \& Gully, 1997; Van Yperen \& Janssen, 2002). Goal orientations are believed to create different perceptual-cognitive frameworks for how individuals approach, interpret, and respond to achievement situations (e.g., Barron \& Harackiewicz, 2000; Duda, 2001; Dweck, 1999; Pintrich, 2000; Van Yperen, 2003). Most attention in the achievement goal tradition has been given to two goal orientations: a mastery orientation and a performance orientation. A mastery orientation focuses on developing competence, gaining skill, and doing one's best, whereas a performance orientation focuses on establishing one's superiority over others.

To date, achievement goal research has been predominantly focused on exploring individual cognition, affect, and behavior related to task engagement and task performance in individual task settings (e.g., Barron \& Harackiewicz, 2000; Button, Mathieu, \& Zajac, 1996; Elliot, 1999; Farr et al., 1993; Ford, Smith, Weissbein, Gully, \& Salas, 1998; Phillips \& Gully, 1997; Pintrich, 2000; Van Yperen, 2003a). Surprisingly, little attention has been given to the question of how goal orientations influence individuals in the way they interpret and respond to the interpersonal context of achievement situations. In most work and organizational settings, employees do not act in isolation but interact with colleagues, supervisors, or customers to perform their job duties. Employees differing in goal orientations are likely to differ in the way they develop and maintain relationships with other actors in their work context. According to leader-member exchange (LMX) theory (for reviews, see Gerstner and Day [1997] and Graen and Uhl-Bien [1995]), each employee establishes a unique social exchange relationship with his or her supervisor, and the quality of this leader-member exchange is generally found to be positively related to job performance and job attitudes.

In the present study, we aimed to develop and test the idea that goal orientations affect how employees develop and maintain social exchanges with their supervisors. More specifically, we argue that mastery orientations cause employees to establish high-quality exchanges with their leaders, whereas performance orientations keep employees from establishing high-quality exchanges with their supervisors. In turn, the quality of leader-member exchange helps employees to be effective on the job in terms of inrole performance, innovative performance, and satisfaction. Thus, we combined achievement goal theory and leader-member exchange theory to propose that the interpersonal mechanism of leader-member exchange mediates the relationships between employees' goal orientations and the outcomes of job performance and job satisfaction.

\section{THEORY AND HYPOTHESES}

In the following sections, we first discuss extant theory and research concerning the relationships between employees' goal orientations, and job performance and job satisfaction. We then consider how a mastery orientation and a performance orientation might differently influence employees in establishing exchange relationships with their su- 
pervisors. Finally, we theorize on how the quality of leader-member exchange facilitates employees' being effective and satisfied on the job.

\section{Goal Orientations and the Outcomes of Job Performance and Job Satisfaction}

Goal orientations are viewed as rather stable personality characteristics fostered by "self-theories" about the nature and development of attributes (such as intelligence, personality, abilities, and skills) people have (Dweck, 1999). As such, a mastery orientation stems from the belief that one's attributes are dynamic and changeable and that exerting effort leads to performance improvement, while a performance orientation stems from the belief that attributes are fixed, concrete, and internal entities. Performance-oriented individuals tend to believe that working hard does not lead to performance improvement. In their view, working hard indicates low competence, and those who perform poorly do not have the attributes necessary to do well in their jobs (Dweck, 1999).

Early research relying on a dichotomous conceptualization of goal orientation repeatedly showed a mastery orientation to be more beneficial for a wide range of task performances than a performance orientation (e.g., Button et al., 1996; Farr et al., 1993; Ford et al., 1998; Phillips \& Gully, 1997; VandeWalle, Brown, Cron, \& Slocum, 1999). However, recent achievement goal research suggests that a performance orientation may also have beneficial effects, particularly with regard to actual performance. To clarify these opposite effects of performance orientation, Elliot and his associates (e.g., Elliot, 1999; Elliot \& Church, 1997) proposed a trichotomous conceptualization of achievement goals by bifurcating performance orientation into a performance-approach orientation and a performance-avoidance orientation (cf. VandeWalle, 1997). They argued that performance-oriented individuals can be motivated either to "outperform" others and to demonstrate their superiority, or to avoid failure and to avoid looking incompetent, respectively. The finding that a performanceapproach orientation is associated with superior performance (e.g., Barron \& Harackiewicz, 2000; Elliot \& Church, 1997; Harackiewicz, Barron, Carter, Letho, \& Elliot, 1997) suggests that individuals with performance-approach orientations tend to exert sufficient effort to accomplish their goal of outperforming others. The tendency to reduce effort after encountering setbacks and difficulty often associated with performance orientations (e.g., Duda, 2001; Dweck, 1999) seems to be more characteristic of performance-avoidance-oriented indi- viduals (Barron \& Harackiewicz, 2000; Elliot, 1999; Pintrich, 2000). Mastery goals were also bifurcated into approach and avoidance versions (Elliot \& McGregor, 2001; Van Yperen, 2003a). That is, individuals endorsing mastery-avoidance goals strive to avoid deterioration, losing their skill, or leaving a task incomplete or unmastered, whereas masteryapproach goals are focused on the development of competence through task mastery (Elliot \& McGregor, 2001). As such, approach-oriented individuals tend to pursue beneficial outcomes, whereas avoidance-oriented employees tend to avert detrimental outcomes. The four different types of goal orientations-that is, mastery approach, mastery avoidance, performance approach, and performance avoidance-appear to have different antecedents and consequences (e.g., Elliot \& McGregor, 2001). However, the different types of goal orientations can coexist in a person, so that, for example, trying to attain mastery is not necessarily inconsistent with striving to outperform others. Thus, people vary in the extent to which they pursue each of the four achievement goals.

Because we had no clear hypotheses regarding the avoidance components of mastery and performance orientations, we focused exclusively on the approach versions. That is, we developed and tested theory proposing that employees with mastery-approach orientations are more effective on the job because of their tendency to establish highquality exchanges with their supervisors, whereas employees with performance-approach orientations are less effective because they fail to establish exchanges of a high quality with their supervisors. For the remainder of this article, we restrict the use of the terms "mastery goal" and "performance goal" to the approach versions of these goal orientations.

As it stands now, achievement goal theory suggests that both mastery-oriented and performanceoriented individuals are strongly motivated to meet their respective performance standards. However, in work and organizational settings, mastery-oriented and performance-oriented employees may differ in the aspects of job performance they focus on. Job performance is a broad and complex construct comprising two fundamentally different aspects, namely, in-role job performance mandated by an organization, and more spontaneous innovative work behaviors (Katz, 1964). So far as we know, no research has been conducted to answer the question of how the different goal orientations relate to these fundamentally different aspects of job performance.

In-role job performance can be defined as actions specified and required by an employee's job description and thus mandated, appraised, and re- 
warded by the employing organization. These sets of rules and procedures make work behavior predictable so that basic organizational tasks can be coordinated and controlled in order to achieve organizational goals. The proficiency with which employees carry out their work activities and work roles appears to be an important individual source of variation in job performance (Borman \& Motowidlo, 1993; Motowidlo \& Van Scotter, 1994). Because a mastery orientation creates a tendency to improve proficiency on the job and to persist effectively in the face of obstacles (cf. Dweck, 1999), mastery-oriented employees can be expected to meet or even exceed their organization's standards for in-role job performance. However, we also expected that performance goal orientations would motivate employees to perform well with respect to in-role task requirements. A performance goal reflects the desire to demonstrate superior competence to others. As such, employees with performance orientations tend to perceive in-role job requirements as competitive standards that motivate them to exert effort in order to outperform others and to obtain favorable competence judgments from their organization's appraisal and reward systems. Moreover, performance goal orientations have been argued to cause employees to rehearse job components and skills until they require little attention and can be performed automatically in a very efficient and effective manner (Steele-Johnson, Beauregard, Hoover, \& Schmidt, 2000). Accordingly, the following hypotheses were formed:

Hypothesis 1. A mastery orientation is positively related to in-role job performance.

\section{Hypothesis 2. A performance orientation is positively related to in-role job performance.}

An organization has to find the right balance between using rules and procedures to make work performance predictable and giving employees the freedom to spontaneously innovate to adapt to problems, opportunities, and unusual situations (cf. Jones, 2001; Katz, 1964). Innovative job performance can be defined as the intentional generation, promotion, and realization of new ideas within a work role, work group, or organization in order to benefit role performance, a group, or an organization (e.g., Kanter, 1988; Scott \& Bruce, 1994; West \& Farr, 1989). A mastery goal orientation can be expected to be an important motivational source for innovative job performance for several reasons. First, individuals pursuing mastery goals have a preference for challenging and complex tasks (Ames \& Archer, 1988; VandeWalle, 1997). Innova- tion is an especially complex and challenging task encompassing a broad variety of cognitive and social activities, such as generating, promoting, discussing, modifying, and ultimately implementing creative ideas (Kanter, 1988). Moreover, innovative job performance concerns the development and application of something new for which the requisite knowledge and strategies have yet to be learned. Research has shown that a mastery goal focuses an individual's attention on the elaboration and development of new knowledge and deep processing strategies leading to effectiveness in complex and unfamiliar tasks (Elliot \& McGregor, 2001; Fisher \& Ford, 1998; Steele-Johnson et al., 2000; Winters \& Latham, 1996).

Second, mastery-oriented employees have personal and intrinsic interest in the tasks they perform (Barron \& Harackiewicz, 2000; Elliot, 1999; Pintrich, 2000; Van Yperen, 2003a). Creativity is evoked by the pleasure provided by the tasks themselves, and the innovation literature emphasizes that this intrinsic aspect of work motivation is an essential motivational base for performing innovative activities (e.g., Amabile, 1988; Redmond, Mumford, \& Teach, 1993). According to Amabile (1985, 1988), intrinsic motivation affects innovativeness by influencing the likelihood that alternative-and potentially more innovative-response possibilities will be explored during task engagement.

Third, when obstacles such as demanding task difficulties are encountered, mastery-oriented employees tend to deal with these challenging circumstances by putting more effort into their jobs (Dweck, 1999; Farr et al., 1993). As has already been mentioned above, innovation requires a broad variety of cognitive and sociopolitical efforts from individual innovators (e.g., Kanter, 1988). Moreover, innovation involves change that may give rise to resistance because of the insecurity and uncertainty it may bring (Frost \& Egri, 1991; Janssen, 2003; Jones, 2001). Hence, innovative employees are likely to meet resistance from other workers in their work environment who want to prevent innovative change. Convincing those workers of the benefits of innovation can be difficult and demanding. Mastery-oriented employees are likely to cope effectively with such difficulties by putting substantial effort into the job of innovation in order to identify and apply the strategies needed to succeed (cf. Dweck, 1999; Farr et al., 1993).

In contrast with a mastery goal orientation, a performance orientation might be less beneficial for innovative behaviors on the job. Fisher and Ford (1998) found that performance orientations cause individuals to rehearse task strategies and familiar 
task components until they become rapid and automatic. Such a focus on practicing job components can interfere with innovation and learning as individuals possess a fixed number of attentional resources that can be allocated to a variety of job components (e.g., Steele-Johnson et al., 2000). Performance-oriented employees tend to devote their attention to surface processing (Elliot \& McGregor, 2001; Elliot et al., 1999) and practicing in-role job components that may help them to outperform others. This focus on surface processing and practicing in-role job components further refines and establishes the existing framework for doing things and is likely to prevent employees from devoting attentional resources to developing innovative ideas for doing things differently.

Furthermore, performance-oriented employees have an extrinsic work motivation in the sense that they tend to define success on the job primarily in terms of outperforming others and demonstrating superiority. The task of innovation, however, is an uncertain and controversial endeavour. That is, the process and outcomes of innovation are unpredictable, as progress comes in spurts among unforeseen delays, setbacks, and costs (e.g., Kanter, 1988). Moreover, innovation poses a threat to vested interests and alternative courses of action and, therefore, often leads to political problems and failure (Frost \& Egri, 1991; Kanter, 1988). As a consequence, employees with performance orientations may tend to keep away from innovation because innovative tasks imply the risk of failure, which would demonstrate their inferiority rather than the superiority they pursue.

This line of reasoning about the relationship between goal orientation and innovative job performance led to the following hypotheses:

Hypothesis 3. A mastery orientation is positively related to innovative job performance.

Hypothesis 4. A performance orientation is negatively related to innovative job performance.

With regard to the affective outcome of job satisfaction, achievement goal research demonstrates that mastery-oriented individuals derive more satisfaction and enjoyment from their efforts to reach their goals than performance-oriented individuals (e.g., Barron \& Harackiewicz, 2000; Elliot, 1999; Harackiewicz et al., 1997; Pintrich, 2000; Van Yperen \& Janssen, 2002). When increased task requirements are encountered, mastery-oriented individuals direct extra effort to a task itself. They tend to view exerting great effort as a desirable attribute of the self so that, for them, exerting effort is in itself indicative of success (Duda, 2001; Dweck, 1999). In contrast, performance-oriented individuals believe that working hard signifies low ability, which makes them uncertain about their capacities to meet their competitive standards (cf. Dweck \& Leggett, 1988; Van Yperen \& Janssen, 2002). Furthermore, mastery-oriented individuals have predominantly internal loci of perceived control and causality (e.g., Dweck \& Leggett, 1988), whereas performance-oriented individuals typically evaluate task performance on the basis of social comparison criteria that appear to them to be largely outside their personal control (cf. Button et al., 1996; Elliot, 1999; Farr et al., 1993; Philips \& Gully, 1997). The work stress literature has shown that a lack of control is accompanied by negative affective outcomes, especially when task requirements are high (e.g., Karasek \& Theorell, 1990; Van Yperen \& Hagedoorn, 2003). Hence, we hypothesized that a mastery orientation is positively related to job satisfaction, whereas a negative relationship was expected between performance orientation and job satisfaction.

\section{Hypothesis 5. A mastery orientation is posi-} tively related to job satisfaction.

\section{Hypothesis 6. A performance orientation is negatively related to job satisfaction.}

\section{Goal Orientations and the Quality of Leader- Member Exchange}

Leader-member exchange (LMX) theory and research suggest that the quality of the exchanges that develop between employees and their leaders are predictive of performance-related and attitudinal job outcomes, especially for employees (Gerstner \& Day, 1997; Graen \& Uhl-Bien, 1995). LMX theory is unique among leadership theories in its focus on the dyadic exchange relationships between supervisors and each of their subordinates (Gerstner \& Day, 1997). High-quality exchange relationships are characterized by mutual trust, respect, and obligation that generate influence between an employee and his or her supervisor. Low-quality exchange relationship, on the other hand, are characterized by formal, role-defined interactions and predominantly contractual exchanges that result in hierarchy-based downward influence and distance between the parties.

Goal orientations may influence how employees approach, interpret, and establish their relationships with their supervisors. Employees with mastery goal orientations strive to develop their competence, skills, and ability. Given this focus, supervisors should be of interest as valuable 
sources of work-related knowledge, information, and experience that can provide employees with prospects for skill development and self-improvement. Therefore, mastery-oriented employees may tend to frequently seek social exchanges with their leaders in order to discuss and learn how to better deal with emerging problems and opportunities when performing their jobs. These exchange interactions may help employees to succeed in their goal of improving ability and skill.

Furthermore, given mastery-oriented employees' intrinsic work motivation and willingness to work hard, supervisors may provide these employees with support, decision latitude, and freedom so that they can initiate, control, and carry out their tasks without excessive supervision. In turn, employees may reciprocate by working hard, doing extra tasks needed for performance improvement, and performing spontaneous and innovative extrarole behaviors going beyond contractual expectations (e.g., Basu \& Green, 1997; Howell \& HallMerenda, 1999; Sparrowe \& Liden, 1997; Wayne, Shore, \& Liden, 1997). As such, exchanges between mastery-oriented employees and their supervisors are likely to develop to high levels. That is, they can count on each other for support and loyalty, share important informational and behavioral resources, and base the exchange process on mutual trust, respect, and obligation (cf. Graen \& Uhl-Bien, 1995; Howell \& Hall-Merenda, 1999).

In contrast, employees with performance goal orientations strive to outperform others and to demonstrate superiority. Given this focus, they may perceive supervisors as threats, as their higher rank suggests that their attributes (such as intelligence and abilities) are superior to those of the subordinate employees. Moreover, performanceoriented employees tend to believe that the attributes people have are fixed and primarily a product of innate talent (Dweck, 1999).

Consequently, such employees may see little possibility of ever showing superior competence in their relationships with their supervisors. In exchanges with their supervisors, they will always be confronted, by definition, with their own inferiority. Therefore, employees with performance orientations may prefer to restrict their interactions with their supervisors to the necessary economic exchange behaviors required and mandated by their formal employment contracts. Given their extrinsic work motivation and meaning systems (Dweck, 1999), supervisors might be less willing to provide performance-oriented employees with decision latitude and autonomy for carrying out their tasks. Thus, leader-member exchanges are likely to be formal and impersonal and characterized by eco- nomic exchange behaviors and social-emotional distance between the exchange parties (cf. Graen \& Uhl-Bien, 1995; Howell \& Hall-Merenda, 1999).

This theorizing on goal orientations' influence on how employees establish social exchanges with their supervisors led to the following hypotheses:

Hypothesis 7. A subordinate's mastery orientation is positively related to the quality of leader-member exchange.

Hypothesis 8. A subordinate's performance orientation is negatively related to the quality of leader-member exchange.

\section{Leader-Member Exchange as an Intermediate Interpersonal Mechanism}

Finally, we expected to find that the quality of leader-member exchange is an interpersonal mechanism that mediates the relationships between goal orientation, and job performance and job satisfaction. As argued above, mastery orientations cause employees to establish high-quality exchanges with their leaders, providing them with opportunities for skill development and self-improvement. This proficiency development may help employees to perform well on in-role job duties.

Furthermore, innovative workers depend on their supervisors for the information (data, expertise, political intelligence), resources (materials, space, time), and social-political support (endorsement, legitimacy, backing) necessary to develop, protect, and apply their innovative ideas (Kanter, 1988). As outlined above, mastery-oriented employees are likely to receive these resources and support because they tend to develop high-quality exchange relationships with their supervisors. Prior research has found that such a high quality of leader-member exchange is predictive of innovative job performance (e.g., Basu \& Green, 1997; Scott \& Bruce, 1994).

The support and autonomy that supervisors may provide to mastery-oriented employees may also lead to higher levels of job satisfaction. Employees who feel a sense of self-determination on the job see themselves as the origin of and responsible for work actions and are, therefore, more likely to experience intrinsic rewards and satisfaction from work (cf. Deci \& Ryan, 1985). Moreover, the support and backing of a supervisor can help employees to overcome work-related problems and, therefore, contribute to their job satisfaction. Indeed, previous research has consistently indicated that higherquality levels of leader-member exchange produce higher levels of job satisfaction among employees 
(e.g., Gerstner \& Day, 1997; Green, Anderson, \& Shivers, 1996).

This line of reasoning on the interpersonal mechanism of leader-member exchange led to the following three hypotheses:

Hypothesis 9. Leader-member exchange mediates the positive relationship between a subordinate's mastery orientation and in-role job performance.

Hypothesis 10. Leader-member exchange mediates the positive relationship between a subordinate's mastery orientation and innovative job performance.

Hypothesis 11. Leader-member exchange mediates the positive relationship between a subordinate's mastery orientation and job satisfaction.

Similarly, low-quality leader-member exchange may play a mediating role in the relationship between a performance orientation and innovative job performance. That is, in low-quality exchange relationships, employees cannot count on their supervisors for the extra support and backing needed to move potentially innovative ideas into reality. This anticipated lack of support can be expected to reinforce the tendency of performance-oriented employees to keep away from risky innovative activities. In addition, the low levels of support and autonomy received from their supervisors may clarify why performance-oriented employees experience relatively low job satisfaction. These arguments suggest the following hypotheses:

Hypothesis 12. Leader-member exchange mediates the negative relationship between a subordinate's performance orientation and innovative job performance.

Hypothesis 13. Leader-member exchange mediates the negative relationship between $a$ subordinate's performance orientation and job satisfaction.

Because of the low-quality exchanges between performance-oriented employees and their supervisors, performance-oriented employees can be expected to use sources other than leader-member exchange to perform in-role job duties well. As noted earlier, performance orientations may cause employees to rehearse components and skills until they require little attention and can be performed in efficiently and effectively.

\section{METHODS}

\section{Sample and Procedures}

The relationships between goal orientations, leader-member exchange, and the outcomes of job performance and job satisfaction were examined in a field study conducted in a division of a Dutch energy supplier. The data were collected as part of a more general survey of job-related attitudes and job performance among nonmanagement lowerlevel employees. These employees performed a wide range of different jobs in different functions, including customer service, meter reading, front office work, back office work, invoicing, collection, accounting, and call center work. Meetings were scheduled to inform the employees about the general purpose of the study, to emphasize confidentiality, and to administer questionnaires. All 288 employees were asked to participate in the research and received questionnaires, which were filled out during work time and returned via the internal mail system.

Of the 288 employees who received questionnaires, 187 responded by providing "self-reports" of their goal orientations, leader-member exchange, and job satisfaction, resulting in a response rate of 65 percent. Since supervisors played a pivotal part in appraisal and rewards systems, the employees' job performance was rated by their immediate supervisors $(n=14)$, who filled out a questionnaire that assessed the in-role and innovative job performance of their subordinates. Supervisor ratings were obtained for 170 of the 187 respondents in the sample.

Of this final sample of 170 respondents, 75 percent were male. Their ages ranged from 19 to 61 years, averaging 44.09 years (s.d. $=9.52)$. The organizational tenure of the participants ranged from less than 1 year to 41 years, and their average tenure was 19.32 years (s.d. $=10.49$ ).

\section{Measures}

The items comprising the scales described generally below are detailed in the first two tables, in the results section.

Goal orientations. Individual differences in goal orientation were assessed by administering scales for measuring mastery and performance goal orientation developed by Van Yperen (e.g., Van Yperen \& Janssen, 2002). The subjects responded to the question "I feel most successful in my job when ...," after which they judged 11 mastery and 8 performance orientation items. Responses were provided on a seven-point scale ranging from 1, "strongly disagree," to 7 , "strongly agree." The 
scales achieved high levels of internal reliability, .90 for mastery orientation and .91 for performance orientation.

Quality of leader-member exchange. This variable was assessed using seven items based on the member versions of leader-member exchange questionnaires developed and used in prior research (e.g., Liden \& Graen, 1980; Scandura \& Graen, 1984; Wayne, Shore, \& Liden, 1997). Respondents indicated the extent to which the items characterized the quality of their exchange relationships with their supervisors (1, "to a very low extent," to 7, "to a very high extent"; $\alpha=.93$ ).

Job performance. We measured in-role job performance using Podsakoff and MacKenzie's (1989) five-item scale for in-role job performance. The immediate supervisors of the respondents indicated the extent to which they agreed or disagreed with five statements about the quality and quantity of the respondents' in-role activities (1, "strongly disagree," to 7 , "strongly agree"; $\alpha=.85$ ).

Innovative job performance was assessed using Janssen's $(2000,2001)$ nine-item scale of individual innovation in the workplace, which draws on Kanter's (1988) work on the stages of innovation. Three items refer to idea generation, three items to idea promotion, and the remaining three to idea realization. Immediate supervisors rated how often the subjects performed the nine innovative work behaviors in the workplace (1, "never," to 7, "always"). A high reliability was achieved for the innovative job performance scale $(\alpha=.98)$.

Job satisfaction. Satisfaction on the job was measured using a five-item scale developed by Bacharach, Bamberger, and Conley (1991). This general job satisfaction scale "emphasizes the match between expectations and perceived reality for broad aspects of the job taken as a whole" (Bacharach et al., 1991: 45). Appropriate to the context of this study, this operational definition of job satisfaction allowed us to examine the extent to which employees' goal orientations on the job were related to the fulfilment of their job expectations. The subordinates responded to the question "How satisfied or dissatisfied are you with ..." (1, "very dissatisfied," to 7 , "very satisfied"; $\alpha=.88$ ), after which they judged five aspects of their jobs.

Covariates. To control for the possibility that sociodemographic differences in the predictor and outcome variables might lead to spurious relationships, gender (1, "male," 2, "female"), age (in years), and organizational tenure (in years) were entered as covariates in the analyses.

\section{RESULTS}

\section{Response Bias}

From the initial sample of 187 respondents, 17 were excluded as a result of missing supervisor ratings, leading to a final sample of 170 respondents. To test whether the included respondents systematically differed from the excluded respondents with respect to their scores on goal orientation, leader-member exchange, and job satisfaction, we conducted a multivariate analysis of variance (MANOVA). The results of the MANOVA did not demonstrate significant differences, minimizing concern about potential sampling bias.

\section{Exploratory Factor Analyses}

Before testing the hypotheses, we conducted two exploratory factor analyses in order to get some evidence for the measures' discriminant validity. First, the items of the self-reported measures of mastery orientation, performance orientation, leader-member exchange, and job satisfaction were submitted to a principal components analysis with oblique rotation. As can be seen in Table 1, four factors emerged with eigenvalues greater than 1, accounting for 61.84 percent of the variance. Each item "loaded" on its appropriate factor, with primary loadings exceeding .44 and cross-loadings lower than .33. Second, the items of the job performance measures rated by the respondents' supervisors were submitted to a principal components analysis with oblique rotation. As is shown in Table 2, the two factors that emerged appropriately represented the in-role and innovative job performance items, whereby primary loadings exceeded .68 while cross-loadings were lower than .34 . The two factors had eigenvalues greater than 1 and accounted for 83.51 percent of the variance.

\section{Descriptive Statistics and Correlations}

Means, standard deviations, and zero-order Pearson correlations among all variables in this study are presented in Table 3. As expected, mastery orientation appeared to be positively correlated to the mediating variable of leader-member exchange and to the outcome variables of in-role job performance, innovative job performance, and job satisfaction. However, no significant zero-order correlations were found between performance orientation and the mediating and outcome variables. As predicted, leader-member exchange was positively related to both in-role and innovative job performance, and to job satisfaction. 
TABLE 1

Results of Principal Components Analysis of Mastery Orientation, Performance Orientation, LeaderMember Exchange, and Job Satisfaction ${ }^{\mathrm{a}}$

Factors

$\begin{array}{lllll}\text { Items } & 1 & 2 & 3 & 4\end{array}$

\section{Mastery orientation}

I feel successful on my job when ... .

I acquire new knowledge or learn a new skill by trying hard.

I acquire new knowledge or master a new skill which was difficult for me in the past.

I learn something that motivates me to continue.

I feel I am improving.

I learn something that makes me want to practice more.

I learn something new that is fun to do.

I get the maximum out of myself.

I improve on particular aspects.

I master new knowledge or a new skill.

I perform to my potential.

I do my very best.

$\begin{array}{lrrr}\mathbf{8 4} & .02 & .04 & -.01 \\ \mathbf{. 8 3} & -.07 & .05 & -.20 \\ \mathbf{8 2} & -.08 & -.04 & -.05 \\ \mathbf{. 8 0} & -.07 & -.04 & -.05 \\ .77 & .17 & -.03 & .03 \\ \mathbf{. 6 8} & .12 & .21 & -.08 \\ \mathbf{. 6 0} & .12 & -.10 & .23 \\ \mathbf{. 5 9} & -.07 & -.10 & .05 \\ \mathbf{. 5 8} & .24 & .19 & -.12 \\ \mathbf{. 4 5} & -.06 & .11 & .10 \\ \mathbf{. 4 4} & .13 & .04 & .23\end{array}$

Performance orientation

I feel successful on my job when ...

I perform better than my colleagues.

Others cannot do as well as me.

Others mess up and I do not.

I can clearly demonstrate that I am the best qualified person.

I accomplish something where others failed.

I am clearly the most productive employee.

I am the only one who knows about particular things or who has a particular skill.

I am the best.

-.05
.06
-.03
.02
.04
-.08
-.04
.32

\section{.85}

\section{.84}

78

.78
.78

.77

.75

.56

$-.04$

.02

.01

$-.03$

.03

.01

.08

My supervisor understands my problems and needs.

My supervisor recognizes my potential.

\section{Job satisfaction}

How satisfied or dissatisfied are you with ...

The progress you are making toward the goals you set for yourself in your present

Your present job in light of your career expectations.

Your present job when you compare it to jobs in other organizations.

The chance your job gives you to do what you are best at.

Your present job when you consider the expectations you had when you took the job.

Eigenvalue

Percentage of variance explained position.

\begin{tabular}{rrrr}
-.03 & .08 & .07 & $\mathbf{. 8 1}$ \\
& & & \\
.13 & -.10 & -.12 & $\mathbf{. 8 1}$ \\
-.08 & .02 & .12 & $\mathbf{. 8 1}$ \\
.04 & -.06 & .03 &. $\mathbf{7 9}$ \\
-.05 & .02 & .14 & .77 \\
& & & \\
7.29 & 3.22 & 5.93 & 2.73 \\
23.52 & 10.38 & 19.12 & 8.82 \\
\hline
\end{tabular}

${ }^{\text {a }}$ Items are quoted from our survey. Boldface indicates a significant loading.

\section{Test of the Hypothesized Model}

Hierarchical regression analyses consisting of two successive steps were conducted to test Hypotheses 1-8. In the first step, the sociodemographic variables were entered as covariates to con- trol for relationships with goal orientation, leadermember exchange, job performance, and job satisfaction. In the second step, we included mastery and performance orientation to test their hypothesized effects on the mediating and outcome 
TABLE 2

Results of Principal Components Analysis of In-Role and Innovative Job Performance ${ }^{\mathrm{a}}$

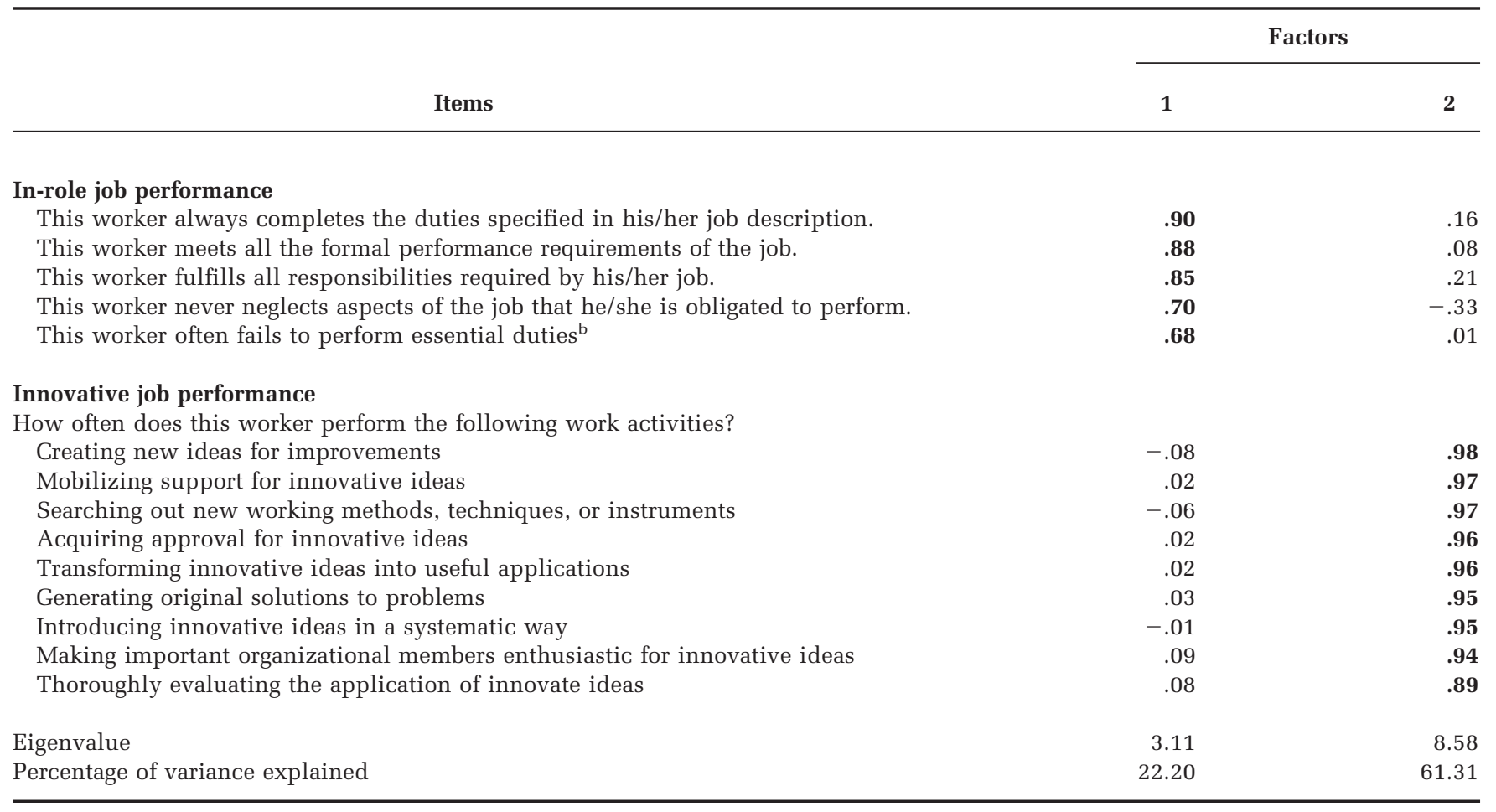

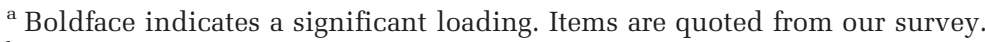

${ }^{\mathrm{b}}$ Reversed.

TABLE 3

Univariate Statistics and Pearson Correlations among the Variables ${ }^{\mathrm{a}}$

\begin{tabular}{|c|c|c|c|c|c|c|c|c|c|c|}
\hline Variable & Mean & s.d. & 1 & 2 & 3 & 4 & 5 & 6 & 7 & 8 \\
\hline 1. Gender & 1.25 & 0.43 & & & & & & & & \\
\hline 2. Age & 44.09 & 9.52 & -.46 & & & & & & & \\
\hline 4. Mastery goal orientation & 5.61 & 0.88 & .09 & -.14 & -.14 & & & & & \\
\hline 5. Performance goal orientation & 3.97 & 1.28 & .01 & -.07 & -.08 & .33 & & & & \\
\hline 6. Leader-member exchange & 3.48 & 0.89 & .12 & -.01 & .04 & .26 & -.07 & & & \\
\hline 9. Job satisfaction & 4.89 & 1.11 & .18 & .13 & .15 & .22 & -.03 & .37 & .08 & .09 \\
\hline
\end{tabular}

${ }^{a}$ Correlations above .16 are significant at the .05 level, and those above .19 are significant at the .01 level. Tests of significance were two-sided. $n=170$.

variables. For all the regression equations reported below, we checked the underlying model assumptions. By comparing the standardized residuals with the predicted values, we detected nine outliers (outside three standard deviations) for in-role job performance and three outliers for job satisfaction. These outliers were left out of the respective regression analyses reported below. It is noteworthy that additional analyses showed that the outliers' inclusion did not meaningfully change the results and interpretations. No major violations were found in the normal probability plots of standardized residuals.

As shown in Table 4, a mastery orientation was positively related to the outcome variables of inrole job performance, innovative job performance, and job satisfaction (see step 2 of the regression equations). These findings were in line with Hypotheses 1, 3, and 5, respectively. Furthermore, as Hypothesis 7 predicts, a mastery orientation was found to be positively related to the mediating variable of leader-member exchange. Contrary to Hy- 
TABLE 4

Results of Regression Analyses ${ }^{a}$

\begin{tabular}{|c|c|c|c|c|c|c|c|c|c|c|c|}
\hline Step and Variables & \multicolumn{3}{|c|}{ In-Role Job Performance } & \multicolumn{3}{|c|}{ Innovative Job Performance } & \multicolumn{3}{|c|}{ Job Satisfaction } & \multicolumn{2}{|c|}{$\begin{array}{l}\text { Leader- } \\
\text { Member } \\
\text { Exchange }\end{array}$} \\
\hline 1. Gender & .15 & .13 & .09 & .10 & .09 & .05 & .03 & .03 & -.02 & .15 & .14 \\
\hline Age & -.17 & -.16 & -.14 & $-.51 * * *$ & $-.50 * * *$ & $-.48 * * *$ & .21 & .26 & .25 & -.08 & -.06 \\
\hline $\begin{array}{l}\text { Performance } \\
\text { orientation }\end{array}$ & & $-.26 * *$ & $-.22^{* *}$ & & -.01 & .04 & & $-.13^{+}$ & -.09 & & $-.16^{*}$ \\
\hline $\begin{array}{l}\text { 3. Leader-member } \\
\text { exchange }\end{array}$ & & & $.30 * * *$ & & & $.30 * * *$ & & & $.27 * * *$ & & \\
\hline$\Delta R^{2}$ & .04 & $.11 * * *$ & $.08^{* * *}$ & $.11^{* * *}$ & $.03^{*}$ & $.08^{* * *}$ & .03 & $.11 * * *$ & $.06^{* * *}$ & .03 & $.09 * * *$ \\
\hline Adjusted $R^{2}$ & .02 & $.12 * *$ & $.20 * * *$ & $.09 * * *$ & $.12 * * *$ & $.19 * * *$ & .01 & $.11^{* * *}$ & $.17^{* * *}$ & .01 & $.09^{* *}$ \\
\hline
\end{tabular}

a Standardized regression coefficients are reported for the respective regression steps, including sociodemographics (step 1), sociodemographics and goal orientations (step 2), and sociodemographics, goal orientations, and leader-member exchange (step 3). For the regression of in-role job performance, $n$ was 161 . For innovative job performance and leader-member exchange, $n$ was 170 . For job satisfaction, $n$ was 167 .

${ }^{+} p<.05$ (one-tailed test)

$* p<.05$ (two-tailed test)

$* * p<.01$ (two-tailed test)

$* * * p<.001$ (two-tailed test)

potheses 2 and 4 , a performance orientation was found to be negatively related to in-role job performance and unrelated to innovative job performance. In line with Hypotheses 6 and 8, a performance orientation was negatively related to job satisfaction and leader-member exchange.

Furthermore, the quality of leader-member exchange was hypothesized to mediate the effects of goal orientation on job performance and job satisfaction. Under the guidelines provided by Baron and Kenny (1986), mediation is indicated if the effect of the independent variable (here, goal orientation) on the outcome variable (job performance and job satisfaction) substantially decreases upon the addition of the mediator (leader-member exchange) to the model, while the mediator has a significant, unique effect on the outcome variable. To test this mediation model, we added a third step, containing leader-member exchange, to the regression analyses of the outcome variables. As is shown in Table 4, when leader-member exchange was added to the models, the regression coefficients of the relationships between mastery orientation and the outcome variables decreased from $.33(p<.001)$ in the second step to $.24(p<.01)$ in the third step for in-role job performance, from .19 $(p<.05)$ to .09 (n.s.) for innovative job performance, and from $.35(p<.001)$ to $.26(p<.001)$ for job satisfaction. Moreover, although the effect of mastery orientation decreased, leader-member ex- change as a mediator had a significant, unique effect on all three outcome variables. With respect to performance orientation, the regression coefficients only slightly decreased from $-.26(p<.01)$ in the second step to $-.22(p<.01)$ in the third step for in-role job performance, and from $-.13(p<.05)$ to -.09 (n.s.) for job satisfaction when we added leader-member exchange to the models.

Finally, to test whether the effect of goal orientation significantly decreased upon the addition of leader-member exchange, we performed the Sobel test (Baron \& Kenny, 1986; Sobel, 1982). This test revealed that leader-member exchange mediated the positive effects of mastery orientation on in-role job performance $(Z=2.71, p<.01)$, innovative job performance $(Z=2.84, p<.01)$, and job satisfaction $(Z=2.74, p<.01)$. Thus, these results provided full support for Hypotheses 9, 10, and 11. Leader-member exchange was not found to be a significant mediator in the relationship between performance orientation and in-role job performance $(Z=-1.45$, n.s.). Furthermore, since performance orientation was not significantly related to the outcome variable of innovative job performance, the results provided no support for Hypothesis 12 , predicting leader-member exchange to be a mediator variable in the negative effect of performance orientation on innovative job performance. Finally, in line with Hypothesis 13, leader-member exchange mediated the negative relationship be- 
tween performance orientation and job satisfaction $(Z=-1.80, p<.05$, one-tailed test).

\section{Supplementary Analyses}

The modest correlation between mastery and performance orientations $(r=.33, p<.001)$ indicates that trying to attain mastery is not necessarily inconsistent with striving to outperform others. By implication, a mastery and a performance goal orientation might interact in their effects. Therefore, we conducted additional hierarchical regression analyses to detect possible interactions. These regressions consisted of three steps. After controlling for the sociodemographic variables in step 1 and the "main effects" of the goal orientations in step 2 , we added the third step, which involved the crossproduct term of mastery and performance orientation, in order to detect interactive effects. To minimize problems of multicollinearity and facilitate interpretation, we centered the predictor variables before calculating the cross-product term and regression statistics (Aiken \& West, 1991). The analyses showed that mastery and performance orientations did not interact in their effects on leadermember exchange $\left(\Delta R^{2}=.01\right.$, n.s.), innovative job performance $\left(\Delta R^{2}=.01\right.$, n.s.), and job satisfaction $\left(\Delta R^{2}=.01\right.$, n.s. $)$. However, we found an interactive effect of mastery and performance orientations on in-role job performance $\left(\Delta R^{2}=.03, b=.11, p<\right.$ $.05)$. To interpret this interaction effect, we rearranged the total regression equation into simple regressions of in-role job performance on performance orientation, given conditional values of mastery orientation (mean +1 s.d.; mean -1 s.d.; cf. Aiken \& West, 1991). As shown in Figure 1, in the case of a strong mastery orientation, relatively high levels of in-role job performance were obtained regardless of the strength of an individual's performance orientation ( $b=-.05$, n.s.). However, when mastery orientation was weak, performance orientation had a negative relationship with in-role job performance $(b=-.24, p<.001)$. These findings signify that mastery and performance orientations interacted in such a way that a strong mastery orientation was needed to buffer the negative effect of a performance orientation on in-role job performance (cf. Van Yperen \& Janssen, 2002). These additional results contradicted Hypothesis 2, which predicts a positive relationship between performance orientation and in-role job performance.

In this article, goal orientations are viewed as rather stable personality characteristics that may influence employees in the way they establish exchange relationships with their leaders. However, alternatively, the quality of leader-member exchange might be a contextual factor that can impact the goal orientations of employees. Therefore, we conducted a series of regression analyses to test alternative path models in which mastery and performance orientations mediated the effects of leader-member exchange on the outcome variables. After controlling for the sociodemographic variables in the first step, we found that leader-member exchange was positively related to in-role job performance $\left(\Delta R^{2}=.13, b=.37, p<.001\right)$, innovative job performance $\left(\Delta R^{2}=.10, b=.32, p<.001\right)$, and job satisfaction $\left(\Delta R^{2}=.12, b=.35, p<.001\right)$. When mastery orientation and performance orientation were added to the equations, the regression coefficients of the relationships between leader-member exchange and the outcome variables declined only

FIGURE 1

Effects of Interaction of Performance and Mastery Orientation on In-Role Job Performance

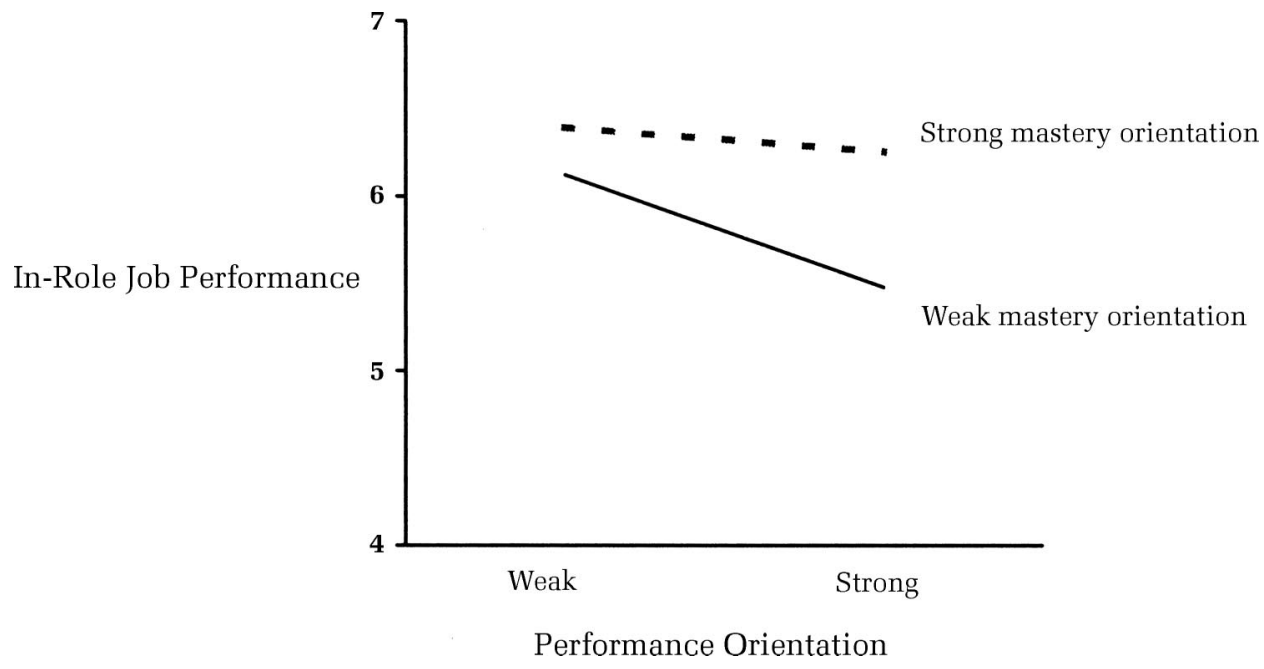


modestly, from $.37(p<.001)$ to $.30(p<.001)$ for in-role job performance, from $.32(p<.001)$ to .30 $(p<.001)$ for innovative job performance, and from $.35(p<.001)$ to $.28(p<.001)$ for job satisfaction. Additional Sobel tests indicated that neither a mastery $(Z=1.11$, n.s.) nor a performance orientation ( $Z=-0.05$, n.s.) mediated the relationship between leader-member exchange and innovative job performance.

Furthermore, performance orientation had no significant mediation effects in the regressions of in-role job performance ( $Z=0.22$, n.s.) and job satisfaction ( $Z=0.57$, n.s.). Only mastery orientation was found to be a modest mediator in the relationships between leader-member exchange and the outcome variables of in-role job performance $(Z=2.19, p<.05)$ and job satisfaction $(Z=$ $2.47, p<.05)$. This pattern of results indicated that the alternative model, in which leader-member exchange is the independent variable and goal orientation is the mediator variable, was inferior to the research model, in which goal orientation is the independent variable, and leader-member exchange is the mediator variable.

Furthermore, as 14 supervisors provided performance ratings across 170 employees, the data had potential for bias owing to differences between supervisors in performance evaluations. Moreover, the 170 respondents were nested within 14 organizational units led by those 14 supervisors and varying more or less in structure, culture, size, kind of jobs, technology, and so forth. To consider this nested data structure and check for possible supervisor and unit effects, we conducted two-level analyses using the MLwiN computer package (Goldstein et al., 1998). These two-level analyses decomposed the total observed variance in the variables of interest into individual-level and grouplevel residual variances We conducted a two-level analysis for each of the three outcome variables. That is, after supervisor and unit effects as well as the sociodemographic variables had been controlled for, mastery orientation, performance orientation, and leader-member exchange were added to the models, to predict the outcome variables. These two-level analyses provided the same pattern of results that we obtained from the ordinary hierarchical regression analyses reported above. That is, leader-member exchange was again found to mediate the positive effects of mastery orientation on in-role job performance, innovative job performance, and job satisfaction. Moreover, performance orientation again interacted with mastery orientation in predicting in-role job performance.

\section{DISCUSSION}

In this study, we developed and tested the idea that a mastery orientation helps an employee to establish a high-quality exchange with his or her leader, while a performance orientation hinders leader-member exchange of a high quality. In turn, the quality of leader-member exchange was assumed to clarify why employees with stronger mastery orientations are more effective on the job than those with stronger performance orientations. As expected, the present survey results revealed that a mastery orientation was positively related to inrole job performance, innovative job performance, and job satisfaction, and that the quality of leadermember exchange mediated these relationships. In contrast, their performance goal orientations led employees to establish low-quality social exchanges with their supervisors. A lower quality of leader-member exchange was associated with lower levels of in-role and innovative job performance, and with lower job satisfaction. However, leader-member exchange was found to be only a mediator in the negative relationship between performance orientation and job satisfaction. Our data provided no evidence that a low-quality leadermember exchange was the interpersonal mechanism that could clarify the negative relationship between performance orientation and job performance.

These results provide new insights for the achievement goal theory, in which the interpersonal context of achievement situations has been largely neglected. In organizational settings, supervisors are an organization's most salient agents for employees, as they principally determine the important job products of subordinates. This study provides theoretical logic and empirical evidence that employees' goal orientations are related to the quality of social exchanges they develop and maintain with their supervisors. In turn, the quality of leader-member exchange facilitates employees' job effectiveness in terms of in-role and innovative job performance and job satisfaction.

Furthermore, the results shed new light on the relationship between goal orientation and job performance. Achievement goal theory suggests that both mastery-oriented and performance-oriented individuals are strongly motivated to meet their respective achievement goals. This high level of motivation is assumed to clarify the positive effects of both goal orientations on actual performance that have been documented in several studies (e.g., Barron \& Harackiewicz, 2000; Elliot \& Church, 1997; Ford et al., 1998; Harackiewicz et al., 1997; Utman, 1997; VandeWalle et al., 1999). Most of the studies 
that have reported positive links between performance orientation and actual performance have been conducted among children and college students carrying out fixed cognitive tasks in educational or laboratory settings (e.g., Barron \& Harackiewicz, 2000; Elliot \& Church, 1997; Ford et al., 1998; Harackiewicz et al., 1997). However, in the current study, conducted among employees of an organization in the energy sector, a performance orientation in itself appeared to be negatively related to in-role job performance. Supplementary analyses showed that this negative relationship was buffered by a strong mastery orientation. That is, the level of in-role job performance was high among employees with high ratings for a performance orientation only when they had high ratings on mastery orientation as well. An explanation of the present findings may be that a strong mastery orientation shifts the focus away from typical performance-oriented cognitions and evaluation criteria, buffering or moderating the negative consequences of a performance orientation (Van Yperen \& Janssen, 2002). This result underscores the need to pay more attention to the development of multiple-goal models in achievement goal research (Barron \& Harackicwicz, 2000; Pintrich, 2000). An interesting question is whether individuals hold performance and mastery goals in mind simultaneously, or whether they alternate between goal states (cf. Harackiewicz et al., 1997). At any rate, the positive correlation between mastery orientation and performance orientation $(r=.33)$ found in the present study seems to indicate that these different orientations tend to coexist in a person. The common component responsible for this correlation might be the approach-oriented achievement motivation reflected in both orientations that directed employees to pursue beneficial outcomes rather than to avert detrimental outcomes (Elliot \& McGregor, 2001). As such, the positive correlation between mastery and performance orientations may call into question the common assumption that the different goal orientations can be conceived of as orthogonal dimensions.

Furthermore, a performance orientation was found to be unrelated to innovative job performance. The present findings suggest that a performance orientation interferes with employees' establishing high-quality relationships with their supervisors. These low-quality leader-member exchanges signify that performance-oriented employees lack important resources for skill development and sociopolitical support, which might clarify why a performance orientation is not advantageous for an employee's innovative job performance.

Apparently, there is much research to be done to improve researchers' understanding of the link between performance orientation and actual performance, including the conditions under which this link may exist (cf. Harackiewicz et al., 2002). Furthermore, more research is clearly needed to further explore the psychological mechanisms underlying the effects of goal orientations (cf. Barron \& Harackiewicz, 2000). For example, VandeWalle and his colleagues (1999) showed that the selfregulation tactics of goal setting, effort, and planning mediated the positive relationship between mastery orientation and job performance, whereas performance orientation was unrelated to these methods of skill development. In addition to those task-oriented tactics, the added value of the current study is that it explicates leader-member exchange as an interpersonal mechanism that mediates the relationship between employees' mastery orientation and effectiveness on the job. An intriguing question that arises from these cumulative results is to what extent a high-quality leader-member exchange process helps employees to focus on skill development by means of self-regulation tactics.

The present study also contributes to the literature on leader-member exchange. Most research in this domain has been conducted to examine how the process of leader-member exchange develops and how the quality of leader-member exchange is related to job performance and job attitudes for employees and supervisors (e.g., Gerstner \& Day, 1997; Graen \& Uhl-Bien, 1995; Liden, Sparrowe, \& Wayne, 1997). However, research devoted to providing knowledge about the antecedents of leadermember exchange has only recently begun (cf. Gerstner \& Day, 1997). Primary research suggests that factors such as relational demography, leadermember similarity, leader delegation, and personality traits of members and leaders influence the development and quality of leader-member exchange (e.g., Gerstner \& Day, 1997; Graen \& UhlBien, 1995; Green et al., 1996; Liden et al., 1997). The present study provides theoretical logic and empirical evidence supporting the idea that goal orientation influences employees' ability to develop and maintain favorable social exchanges with their supervisors. Moreover, the quality of leader-member exchange appeared to clarify why employees with stronger mastery orientations are more effective in terms of in-role job performance, innovative job performance, and job satisfaction. Therefore, future research might examine whether leader-member exchange mediates the influence of goal orientation on other effectiveness variables such as organizational citizenship behaviors and organizational commitment.

Some limitations of this research should also be 
considered. First, the cross-sectional design of the present study did not allow us to determine the direction of causality among the variables. The results are vulnerable to opposite and to bidirectional relationships because of the possibility that an employees' performance and satisfaction might influence the development and quality of leadermember exchange, which, in turn, could shape employees' goal orientations. An argument against such reversed causality is the fact that theory and previous research persuasively present both goal orientation and leader-member exchange as major causes of actual performance and task enjoyment (e.g., Barron \& Harackiewicz, 2000; Button et al., 1996; Farr et al., 1993; Gerstner \& Day, 1997; Graen \& Uhl-Bien, 1995; VandeWalle et al., 1997). Moreover, goal orientations are viewed as rather stable personality characteristics that are fostered by people's self-theories about the nature and development of attributes such as intelligence, personality, and abilities (Dweck, 1999). In contrast, the quality of leader-member exchange is a typical work context variable found to be dependent upon personal characteristics of employees and leaders (e.g., Gerstner \& Day, 1997; Graen \& Uhl-Bien, 1995; Green et al., 1996; Liden et al., 1997). Hence, goal orientation can be considered as an antecedent rather than a consequence of the quality of leadermember exchange. An additional test of alternative path models in which mastery and performance orientations mediated the effects of LMX on the outcome variables confirmed this conclusion. The results demonstrated no mediation effects in the regression of innovative job performance and only modest mediation effects through mastery orientation in the regression analysis of in-role job performance and job satisfaction. Nonetheless, the cross-sectional survey data cannot rule out the alternative suppositions that goal orientation and leader-member exchange are covariates or even consequences rather than causes of effectiveness on the job. Hence, longitudinal and experimental studies are needed to provide evidence of causation.

Although the nature of the performance data (ratings by supervisors) is a strength of the present study, a second limitation concerns possible common method variance in the relationships between the self-reported measures of goal orientation, the mediating variable of leader-member exchange, and the outcome variable of job satisfaction. However, it is hard to imagine that the respondents in this study would have artifactually caused the differing patterns of relationships between mastery orientation and performance orientation, on the one hand, and leader-member exchange and job satisfaction, on the other hand. Moreover, the me- diating effect of leader-member exchange in the relationship between mastery orientation and job satisfaction was identical to the mediating effects in the relationships between mastery orientation and in-role and innovative job performance rated by the immediate supervisors of the respondents. These considerations make us confident that common method variance is not a major concern.

Finally, the sample consisted of lower-level employees from an industrial organization in the energy supply sector. Hierarchical level and particular organizational factors might vary with employees' goal orientations, leader-member exchange, and job attitudes and behaviors. Therefore, generalization of the present results to employees performing their job duties on higher hierarchical levels and in other types of organizations awaits further empirical examination.

Several findings of the current study might have practical implications. In line with prior research conducted in a field setting (VandeWalle et al., 1999), the present results suggest that masteryoriented employees tend to be more effective on the job than performance-oriented employees. A mastery orientation might be of particular value for performing the complex and challenging task of innovation in the workplace. Employees with mastery orientations are intrinsically motivated in their work, tend to invest a lot of effort in their jobs, and attempt to establish high-quality social exchanges with their supervisors. As delineated in the theoretical section of this article, these conditions are needed in order to succeed in the comprehensive tasks of generating, promoting, and implementing innovative ideas. Thus, the results of the present study suggest that innovative job performance is related to an employee's mastery orientation. Therefore, organizations might consider selecting employees with strong mastery orientations for positions and roles directed toward initiating and implementing innovative changes.

Furthermore, although employees' goal orientations are rather stable personal characteristics, they are not indifferent to contextual factors (Ames, 1992; Harackiewicz et al., 1997; Button et al., 1996; Dweck, 1999; Elliot, 1999; Farr et al., 1993; Pintrich, 2000; Van Yperen \& Janssen, 2002). As performance standards, production schedules, deadlines, and the like are an integral part of any job (Button et al., 1996), achievement situations on the job might prompt employees to pursue performance goals (Van Yperen, 2003b). The present findings show that a predominant performance orientation may lead to lower-quality leader-member exchanges and to lower in-role job performance. Accordingly, organizations would be wise to de- 
sign a culture and practices that facilitate mastery orientations among their employees in order to buffer potential detrimental consequences of performance orientations primed by a given achievement situation (cf. VandeWalle et al., 1999; Van Yperen, 2003b). A mastery orientation might be facilitated by, among other things, self-referenced rather than other-referenced feedback and compensation systems that focus on effort, personal improvement, skill development, experimentation, and cooperation (e.g., Ames, 1992).

Finally, VandeWalle and his colleagues (1999) suggested that training employees to change their self-theories and attitudes towards ability, effort, and performance could help them to adopt mastery orientations in the performance of their job duties. That is, employees can be taught to view effort as a key determinant of job performance and proficiency as a malleable attribute that can be developed in many ways. As the results of the present study suggest, focusing on these mastery orientation features is important as doing so enables employees to establish the high-quality leadermember exchanges that are needed for high job satisfaction and effective in-role and innovative job performance.

\section{REFERENCES}

Aiken, L. S., \& West, S. G. 1991. Multiple regression: Testing and interpreting interactions. Newbury Park, CA: Sage.

Amabile, T. M. 1985. Motivation and creativity: Effects of motivational orientation on creative writers. Journal of Personality and Social Psychology, 48: 393-397.

Amabile, T. M. 1988. A model of creativity and innovation in organizations. In B. M. Staw \& L. L. Cummings (Eds.), Research in organizational behavior, vol. 10: 187-209. Greenwich, CT: JAI Press.

Ames, C. 1992. Achievement goals, motivational climate, and motivational processes. In G. C. Roberts (Ed.), Motivation in sport and exercise: 161-176. Champaign, IL: Human Kinetic Books.

Ames, C., \& Archer, J. 1988. Achievement goals in the classroom: Students' learning strategies and motivation processes. Journal of Education Psychology, 80: $260-267$.

Bacharach, S. B., Bamberger, P., \& Conley, S. 1991. Workhome conflict among nurses and engineers: Mediating the impact of role stress on burnout and satisfaction at work. Journal of Organizational Behavior, 12: $39-53$.

Baron, R. M., \& Kenny, D. A. 1986. The moderator-mediator variable distinction in social psychological research: Conceptual, strategic, and statistical consid- erations. Journal of Personality and Social Psychology, 6: 1173-1182.

Barron, K. E., \& Harackiewicz, J. M. 2000. Achievement goals and optimal motivation: A multiple goals approach. In C. Sansone \& J. M. Harackiewicz (Eds.), Intrinsic and extrinsic motivation: The search for optimal motivation and performance: 229-254. San Diego, CA: Academic Press.

Basu, R., \& Green, S. R. 1997. Leader-member exchange and transformational leadership: An empirical examination of innovative behaviors in leader-member dyads. Journal of Applied Social Psychology, 27: 477-499.

Borman, W. C., \& Motowidlo, S. J. 1993. Expanding the criterion domain to include elements of contextual performance. In N. Schmitt, W. C. Borman, \& Associates (Eds.), Personnel selection in organizations: 71-98. San Francisco: Jossey-Bass.

Button, S. B., Mathieu, J. E., \& Zajac, D. M. 1996. Goal orientation in organizational research: A conceptual and empirical foundation. Organizational Behavior and Human Decision Processes, 67: 26-48.

Deci, E., \& Ryan, R. 1985. The support of autonomy and control of behavior. Journal of Personality and Social Psychology, 53: 1024-1037.

Duda, J. L. 2001. Achievement goal research in sport: Pushing the boundaries and clarifying some misunderstandings. In G. C. Roberts (Ed.), Advances in motivation in sport and exercise: 129-182. Champaign, IL: Human Kinetics Books.

Dweck, C. S. 1999. Self-theories: Their role in motivation, personality, and development. Ann Arbor, MI: Psychology Press, Taylor \& Francis Group.

Dweck, C. S., \& Leggett, E. L. 1988. A social cognitive approach to motivation and personality. Psychological Review, 95: 256-273.

Elliot, A. J. 1999. Approach and avoidance motivation and achievement goal. Educational Psychologist, 34: 169-189.

Elliot, A. J., \& Church, M. A. 1997. A hierarchical model of approach and avoidance achievement motivation. Journal of Personality and Social Psychology, 73: $218-232$.

Elliot, A. J., \& McGregor, H. A. 2001. A $2 \times 2$ achievement goal framework. Journal of Personality and Social Psychology, 80: 501-514.

Farr, J. L., Hofmann, D. A., \& Ringenbach, K. L. 1993. Goal orientation and action control theory: Implications for industrial and organizational psychology. In C. L. Cooper \& I. T. Robertson (Eds.), International review of industrial and organizational psychology: 193- 232. Wiley.

Fisher, S. L., \& Ford, J. K. 1998. Differential effects of learner effort and goal orientation on two learning outcomes. Personnel Psychology, 51: 397-420.

Ford, J. K., Smith, E. M., Weissbein, D. A., Gully, S. M., \& 
Salas, E. 1998. Relationship of goal orientation, metacognitive activity, and practice strategies with learning outcomes and transfer. Journal of Applied Psychology, 83: 654-665.

Frost, P. J., \& Egri, C. P. 1991. The political process of innovation. In B. M. Staw \& L. L. Cummings (Eds.), Research in organizational behavior, vol. 13: 229295. Greenwich, CT: JAI Press.

Gerstner, C. R., \& Day, D. V. 1997. Meta-analytic review of leader-member exchange theory: Correlates and construct issues. Journal of Applied Psychology, 82: 827-844.

Goldstein, H., Rasbash, J., Plewis, I., Draper, D., Browne, W., Yang, M., Woodhouse, G., \& Healy, M. 1998. A user's guide to MlwiN. London: University of London.

Graen, G. B., \& Uhl-Bien, M. 1995. Relationship-based approach to leadership: Development of leadermember exchange (LMX) theory of leadership over 25 years: Applying a multi-level multi-domain perspective. Leadership Quarterly, 6: 219-247.

Green, S. G., Anderson, S. E., \& Shivers, S. L. 1996. Demographic and organizational influences on leader-member exchange and related work attitudes. Organizational Behavior and Human Decision Processes, 66: 203-214.

Harackiewicz, J. M., Barron, K. E., Carter, S. M., Lehto, A. T., \& Elliot, A. J. 1997. Predictors and consequences of achievement goals in the college classroom: Maintaining interest and making the grade. Journal of Personality and Social Psychology, 73: 1284-1295.

Howell, J. M., \& Hall-Merenda, K. E. 1999. The ties that bind: The impact of leader-member exchange, transformational and transactional leadership, and distance on predicting follower performance. Journal of Applied Psychology, 84: 680-694.

Janssen, O. 2000. Job demands, perceptions of effortreward fairness, and innovative work behavior. Journal of Occupational and Organizational Psychology, 73: 287-302.

Janssen, O. 2001. Fairness perceptions as a moderator in the curvilinear relationships between job demands, and job performance and job satisfaction. Academy of Management Journal, 44: 1039-1050.

Janssen, O. 2003. Innovative behavior and job involvement at the price of conflict and less satisfactory relations with co-workers. Journal of Occupational and Organizational Psychology, 76: 347-364.

Jones, G. R. 2001. Organizational theory: Text and cases. Reading, MA: Addison-Wesley.

Kanter, R. 1988. When a thousand flowers bloom: Structural, collective, and social conditions for innovation in organizations. In B. M. Staw \& L. L. Cummings (Eds.), Research in organizational behavior, vol. 10: 169-211. Greenwich, CT: JAI Press.
Karasek, R., \& Theorell, T. 1990. Healthy work: Stress, productivity, and the reconstruction of working life. New York: Basic Books.

Katz, D. 1964. The motivational basis of organizational behavior. Behavioral Science, 9: 131- 133.

Liden, R., \& Graen, G. 1980. Generalizability of the vertical dyad linkage model of leadership. Academy of Management Journal, 23: 451-465.

Liden, R. C., Sparrowe, R. T., \& Wayne, S. J. 1997. Leadermember exchange theory: The past and potential for the future. In G. R. Ferris \& K. M. Rowland (Eds.), Research in personnel and human resources management, vol. 15: 47-119. Greenwich, CT: JAI Press.

Motowidlo, S. J., \& Van Scotter, J. R. 1994. Evidence that task performance should be distinguished from contextual performance. Journal of Applied Psychology, 79: 475-480.

Phillips, J. M., \& Gully, S. M. 1997. Role of goal orientation, ability, need for achievement, and locus of control in the self-efficacy and goal-setting process. Journal of Applied Psychology, 82: 792-802.

Pintrich, P. R. 2000. The role of goal orientation in selfregulated learning. In M. Boekaerts, P. R. Pintrich, \& M. Zeidner (Eds.), Handbook of self-regulation: 451-502. San Diego: Academic Press.

Podsakoff, P. M., \& Mackenzie, S. B. 1989. A second generation measure of organizational citizenship behavior. Working paper, Indiana University, Bloomington.

Redmond, M. R., Mumford, M. D., \& Teach, R. 1993. Putting creativity to work: Effects of leader behavior on subordinate creativity. Organizational Behavior and Human Decision Processes, 55: 120-151.

Scandura, T. A., \& Graen, G. B. 1984. Moderating effects of initial leader-member exchange status on the effects of a leadership intervention. Journal of Applied Psychology, 69: 428-436.

Scott, S. G., \& Bruce, R. A. 1994. Determinants of innovative behavior: A path model of individual innovation in the workplace. Academy of Management Journal, 37: 580-607.

Sobel, M. E. 1982. Asymptotic intervals for indirect effects in structural equations models. In S. Leinhart (Ed.), Sociological methodology: 290-312. San Francisco: Jossey-Bass.

Sparrowe, R. T., \& Liden, R. C. 1997. Process and structure in leader-member exchange. Academy of Management Review, 22: 522-552.

Steele-Johnson, D., Beauregard, R. S., Hoover, P. B., \& Schmidt, A. M. 2000. Goal orientation and task demand effects on motivation, affect, and performance. Journal of Applied Psychology, 85: 724-738.

Utman, C. H. 1997. Performance effects of motivational state: A meta-analysis. Personality and Social Psychology Review, 1: 170-182. 
VandeWalle, D. 1997. Development and validation of a work domain goal orientation instrument. Educational \& Psychological Measurement, 57: 9951015.

VandeWalle, D., Brown, S. P., Cron, W. L., \& Slocum, J. W. 1999. The influence of goal orientation and self-regulation tactics on sales performance: A longitudinal field test. Journal of Applied Psychology, 84: 249-259.

Van Yperen, N. W. 2003a. Task interest and actual performance: The moderating effects of assigned and adopted purpose goals. Journal of Personality and Social Psychology, 85: 1006-1015.

Van Yperen, N. W. 2003b. The perceived profile of goal orientation within firms: Differences between employees working for successful and unsuccessful firms employing either performance-based pay or job-based pay. European Journal of Work and Organizational Psychology, 12: 229-243.

Van Yperen, N. W., \& Hagedoorn, M. 2003. Do high job demands increase intrinsic motivation or job strain or both? The role of job control and social support. Academy of Management Journal, 46: 339-348.

Van Yperen, N. W., \& Janssen, O. 2002. Feeling fatigued and dissatisfied or feeling fatigued but satisfied? Employees' goal orientations and their responses to high job demands. Academy of Management Journal, 45: 1161-1171.
Wayne, S. J., Shore, L. M., \& Liden, R. C. 1997. Perceived organizational support and leader-member exchange: A social exchange perspective. Academy of Management Journal, 40: 82-111.

West, M. A., \& Farr, J. L. 1989. Innovation at work: Psychological perspectives. Social Behavior, 4: 1530.

Winters, D., \& Latham, G. P. 1996. The effect of learning versus outcome goals on a simple versus a complex task. Group and Organization Management, 21: $236-250$.

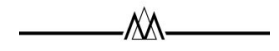

Onne Janssen (o.janssen@ppsw.rug.nl) is an assistant professor of organizational psychology at the University of Groningen, The Netherlands. His current research focuses on the determinants and consequences of employee innovative behavior in organizations.

Nico W. VanYperen is a professor of psychology at the University of Groningen and at the University of Nijmegen, The Netherlands. His research interests include achievement goals, motivation and job performance, and organizational stress. 
Copyright of Academy of Management Journal is the property of Academy of Management and its content may not be copied or emailed to multiple sites or posted to a listserv without the copyright holder's express written permission. However, users may print, download, or email articles for individual use. 